INTERNATIONAL JOURNAL OF
ORGANIZATIONAL LEADERSHIP
ORGANIZATIONAL
LEADERSHIP

\title{
HRM Practices and Organizational Performance of Higher Secondary Educational Institutions: Mediating Role of Service Innovation and Organizational Commitment
}

\author{
Ayesha Nawal ${ }^{1}$, Muhammad Shoaib ${ }^{2 *}$, Asad Ur Rehman ${ }^{3}$, Roman Zámečník ${ }^{4}$ \\ ${ }^{1,3}$ University Sultan Zainul Abidin, Kuala Terengganu, Malaysia. \\ ${ }^{2,4}$ Department of Business Administration, Faculty of Management and Economics, Tomas Bata University in \\ Zlin, Czech Republic
}

Keywords:

HRM practices, Service innovation, Organizational

commitment, Organizational performance, Higher

secondary educational institutions

Received

17 July 2021

Received in revised form

08 August 2021

Accepted

12 August 2021

*Correspondence: shoaib@utb.cz.

\begin{abstract}
Higher secondary educational institutions are criticized for deteriorating performance. However, rare studies addressed the declining performance because of Inadequate HRM practices, low commitment, and staff incompatibility with emerging technological trends. This study intends to examine the influence of HRM practices on service innovation and organizational commitment and their subsequent effect on the performance of higher secondary educational institutions. The study also aims to examine the mediational role of service innovation and organizational commitment. The study also investigates the interrelationship of HRM practices, service innovation, organizational commitment, and organizational performance simultaneously in a single model has not been conducted in higher secondary educational institutions of Pakistan. This study is descriptive, deductive, explanatory, and cross-sectional. Data was collected from 372 staff members working in higher secondary educational institutions, and SEM was used for data analysis. The findings signposted that HRM practices have a positive effect on service innovation and organizational commitment. On the other hand, HRM practices did not have a significant direct positive effect on organizational performance. Moreover, service innovation and organizational commitment positively affected performance and fully mediated the relationship between HRM practices and organizational performance. All the proposed hypotheses were supported except H3. This study offers significant guidelines for educational institutions by predicting the influential factors to improve performance. This study of HRM practices to improve the performance of higher secondary educational institutions with mediating role of service innovation and organizational commitment is a unique theoretical contribution. Consideration of service innovation in education is a noteworthy insight into the literature.
\end{abstract}


Better performance of higher secondary educational institutions is indispensable to cover the enrollment gap at the tertiary level of education (UNESCO, 2018). Moreover, economic growth is less likely to be possible without a corresponding improvement in the performance of higher secondary educational institutions as these institutions are responsible for providing a knowledgeable and skilled workforce to participate in economic activities (Economic Survey of Pakistan, 2018). In an educational context, better performance is denoted as accomplishing desired goals, providing quality education, improvement in student competencies, skill development, better exam scores, modern curriculum, and value-added teaching/learning methods (Hunter, 2020).

In Pakistan, higher secondary educational institutions face performance issues regarding low enrollment-to-completion ratio, lack of adequate financial resources, lack of staff training, higher absenteeism, outdated teaching methods, low commitment, and lack of professional capabilities (Naviwala, 2016). Perhaps most alarming is the highest number of non-enrolled students; approximately 22.7 million students are not attending institutions, and this figure grows up at higher academic ladders (UNESCO, 2018). At the secondary and higher secondary level, approximately $70 \%$ of students are non-enrolled (World Education Services, 2020). The declining enrollment tendency indicates the poor performance of educational institutions (Hunter, 2020). Of the enrolled students, $1 / 3$ percent of students cannot successfully meet the criteria to succeed at the next level, they either fail their higher secondary exam or are unable to attain critical analytical skills and competencies to pass the entry test for university enrollment. Moreover, the Board of Intermediate and Secondary Education (BISE) gazette indicated that students' pass percentage had been declined up to $59.87 \%$ compared to previous years, $69.82 \%$ in 2017, and 74.33\% in 2016 (BISE, 2018).

Educational institutions' survival and consistent performance depend upon maintaining excellent quality, value-added service delivery, up-to-date curriculum, and modern teaching methods (El-Hilali et al., 2015). In an educational context, quality is considered in terms of stakeholder perceptions, quantifiable outcomes, curriculum design, and conformance to standards aligned with the requirements of concerned bodies. Human resource is essential for accomplishing goals and maintaining better performance (Idrus et al., 2018), while goal accomplishment and quality education are performance determinants that depend upon human resources and effective human resource management (Awan, 2019). But, the availability of human resources does not warranty the success of an institution. To attain better performance, institutions are required to appropriately manage their human asset by executing appropriate HRM practices (Cameron \& Grootenboer, 2020).

UNESCO's (2018) report revealed the deplorable condition of staff management in Pakistan's educational institutions, and the situation is grimmer in some parts of Punjab province (Allui \& Sahni, 2016). Besides, a dearth of innovation and outdated teaching methods hamper students' capabilities and hurt the performance of institutions (Bryson et al., 2018). This background information provides a foundation to examine the relationship between HRM practices and organizational performance of higher secondary educational institutions. Moreover, this study proposes service innovation and organizational commitment as mediational constructs.

In Pakistan's context, the performance of higher secondary educational institutions is an under-investigated phenomenon. Previously, HRM practices were addressed at university or 
primary levels (Wolf \& Lasserre-cortez, 2018). But no study has investigated the influence of HRM on the performance of higher secondary educational institutions. HRM practices influence the performance of educational institutions (Manthi et al., 2018) in different contextual backgrounds; a study in a developing country's context can offer better generalizability (Santhanam et al., 2017). Thus, a gap has been observed in the literature that the present study aims to cover. This study contributes to the literature in different aspects. First, this study is among pioneers to propose and empirically examine an integrated model that links HRM practices, service innovation, and organizational commitment with the performance of higher secondary educational institutions of Punjab, Pakistan. Second, this study enlightened the prior literature of service innovation by considering radical and incremental aspects of service innovation in the educational context. Service innovation in education needs further attention, and devoted emphasis can offer better theoretical and practical performance contributions (Carvalho \& Goodyear, 2018). Third, this study broadens the concept of organizational performance by measuring subjective aspects of performance in terms of goal accomplishment, resource management, and external relationship in the educational context.

\section{Theoretical Background}

\section{Resource-Based View (RBV) Theory}

This study considers the resource-based view perspective from the seminal work of Barney (1991) and Teece et al. (1997). The central tenet of RBV is the establishment of valuable, rare, inimitable, and non-substitutable (VRIN) resources to gain differential advantages and better performance (Takeuchi et al., 2007; Teece, 2007). RBV asserted internal organizational resources and capabilities as determinants of higher organizational performance by establishing competitive advantages (Zou \& Stan, 1998). It is a strategic process of developing competencies for allocating and coordinating resources to bring innovation that yields desired outcomes. Acquisition, development, and best amalgamation of human, tangible, and intellectual resources enhance the exclusive value (Barney, 1991). RBV paradigm emphasized enhancing organizational resources, including managerial skills, knowledge, competencies, and staff commitment to improving performance (Barney, Ketchen \& Wright, 2011). Being purely service sector, educational institutions significantly rely on human resource capabilities, skills, knowledge, and commitment to survival. To sustain the performance, educational institutions should utilize human capabilities to offer innovative, competitively unique, and value-added services. By implementing HRM practices, institutions utilize human, intellectual, technological resources, employees' commitment, knowledge, experience, skills, and capabilities to offer their customers innovative and value-added products/services (Poazi et al., 2017). Consideration of RBV states that organizational performance is dependent and significantly influenced by human resources and innovative capabilities to establish a competitive advantage that yields higher performance (Zawawi et al., 2016). Committed human capital and service innovation capabilities are sources to add value to the bottom-line yields by introducing unique products/services, cost efficiency, and quality improvement, consequently enhancing organizational performance (Tsai \& Yang, 2013). 


\section{Conceptual Framework and Hypotheses Development HRM Practices and Service Innovation}

This study used seven HRM practices, recruitment and selection, training and development, compensation and rewards, performance appraisal management, career planning, employee involvement, and employment security. A cluster of these HRM practices is emerging and more influential (Dastmalchian et al., 2020). HRM practices like hiring qualified personnel, skilling, performance appraisal, career planning, and development opportunities enhanced employees' positive concerns towards innovation practices (Dede, 2018). Most innovative firms are more competitive ones. Employment security, employee training with new technologies, and compensation packages positively influence service organizations' innovation (Diaz-Fernandez et al., 2017). Reward strategies and recruitment policies significantly influence the attitude towards innovation, while performance appraisal and career-oriented training programs were found insufficient predictors of innovation (Aman et al., 2018). The HRM system improves group innovation by improving individual proactivity. Team-based recruitment, teamwork training and skilling, team-based performance appraisals, and job rotation at the workplace reduce barriers to innovation (AL-Tal \& Lawrence, 2019). HRM practices influence product innovation, process innovation, administrative innovation, and technological innovation. Theoretical underpinnings of HRM practices and service innovations can be enriched by putting more considerations on radical innovation (Seeck \& Diehl, 2017). This study considers radical and incremental dimensions of service innovation. Thus, we formulate the following hypothesis:

\section{H1: HRM practices have a positive effect on service innovation.}

\section{HRM Practices and Organizational Commitment}

Employees' organizational commitment has been denoted as an intangible outcome of HRM practices that contribute to retaining the best workforce and utilizing their capabilities up to the maximum (Wasti et al., 2016). Different HRM has positive contributions to fosterorganizational commitment among employees (Jawaad et al., 2019). Wasti et al. (2016) believe that better incentives, training, transparent performance appraisal, and performance-based rewards promote committed behaviors among employees. Vivid implementation of effective HRM practices contributes to generating desired committed behavior of employees. The impact of some HRM practices such as performance-based rewards, information sharing, training programs, and pay policies is stronger on overall organizational commitment (Aydoğan \& Arslan, 2020). Highly motivated, skilled, and satisfied employees are outcomes of implementing HRM practices that enhance employees' commitment to their organization and direct their efforts towards goal accomplishment (Sriviboon \& Jermsittiparsert, 2019). Thus, we formulate the following hypothesis:

H2: HRM practices have a positive effect on organizational commitment.

\section{HRM Practices and Organizational Performance}

In the recent decade, the linkage between HRM practices and organizational performance has been evolved in diverse disciplines. However, due to methodological discrepancies, HRM practices are not isolated from a contextual perspective (Brito \& Oliveira, 2016). Effective 
human resource management and the development of optimal potential are essential for successful performance. Effective recruitment and retention system potentially influence employees' perceptions about organizational performance (Gyurák Babel'ová et al., 2020). Recruitment and selection, training and development, rewards and compensation, employees' job involvement, and workplace conditions indicated a positive and significant influence on organizational performance. However, the impact of recruitment and selection is comparatively more significant (Jashari \& Kutllovci, 2020). Training programs, teamwork orientation, incentives, performance management, and employment security are significantly positive to boost the performance of organizations (Omar, Ali, \& Masrom, 2020). Thus, we formulate the following hypothesis:

H3: HRM practices have a positive effect on organizational performance.

\section{Service Innovation and Organizational Performance}

Innovation is one of the most competitive mechanisms and a significant predictor of better organizational performance (Karakaş et al., 2017). Service innovation is a cost-reductive measure to improve efficiency. Embracing service innovation influenced organizational performance (Ehrami, 2017). Sethibe and Steyn (2016) revealed that innovation is an essential determinant to affect organizations' subjective and objective performance. Market innovation, product innovation, process innovation, and organizational innovation as components of service innovation influence the financial and non-financial performance of service organizations (Alkalouti et al., 2020; Sharma \& Bhat, 2020). The present study attempted to investigate the influence of radical and incremental aspects of service innovation on the higher secondary educational institution's performance. Thus, we formulate the following hypothesis:

H4: Service innovation has a positive effect on organizational performance.

\section{Organizational Commitment and Organizational Performance}

Organizations develop committed behaviors of human capital to enhance efficiency and performance (Ebraze et al., 2019). A relationship exists between employees' organizational commitment and performance of institutions, and committed workforce contributed to higher organizational performance (Abebe \& Markos, 2016). Organizational commitment of human resources has been acknowledged as an essential tool to gain excellent performance during the long run (Bahjat et al., 2017). Peachey, Burton, and Wells (2014) argued that employees' higher organizational commitment increased their constructive contributions towards better performance. Employees with a higher level of commitment contribute to maximizing organizational performance (Princy \& Rebeka, 2019). Thus, employees' commitment to organizations plays a vital role in the growth and better performance (Mohamud et al., 2018). Thus, we formulate the following hypothesis:

\section{H5: Organizational commitment has a positive effect on organizational performance.}

\section{Mediating Role of Service Innovation}

Innovation in services mediated the relationship between innovation capability and performance (Rajapathirana \& Hui, 2018). Organizations' differentiation strategy influence service innovation, enhancing organizational performance (Kaliappen \& Hilman, 2014). 
Product innovation, process innovation, market innovation, and organizational innovation exert mediational influence on the relationship between innovation capability and organizations' innovation performance. Innovation is a predictor of market-related organizational performance and fully mediates the influence of employee creativity on performance (Do et al., 2018). Nataya and Sutanto (2018) examined service innovation as a mediator between product innovation and performance, Findings revealed that service innovation partially mediates the relationship between HRM practices and sustainable organizational performance (Ferreira et al., 2021; Rasool et al., 2019). Thus, we formulate the following hypothesis:

H6: Service innovation mediates the relationship between HRM practices and organizational performance.

\section{The Mediating Role of Organizational Commitment}

Organizational commitment is essential to improve organizational performance. Fair rewards, transparent performance appraisal, understanding employees' problems, and offering possible solutions are tactics to create bonding with employees. In response, employees tend to stay with the organization and steadfastly put efforts into better organizational performance (Ehijiele, 2018). Affective commitment exerts a mediational impact on the relationship between HRM practices and workplace learning (Khandakar, Alam \& Pangil, 2020). By executing welldefined HRM practices, organizations can enhance employees' level of commitment, which leads to better organizational performance (Luna-Arocas \& Lara, 2020). Recruitment, training and development, performance management, rewards, and employee retention strongly influence organizational commitment that ultimately boosts organizational performance (Kumari \& Dubey, 2018). Thus, we formulate the following hypothesis:

H7: Organizational commitment mediates the relationship between HRM practices and organizational performance.

\section{Methodology}

\section{Research settings}

Private higher secondary educational institutions' employees are selected as the setting of this study for several reasons. Private higher secondary educational institutions are flourishing in Pakistan, meanwhile criticized for their deteriorating performance and lack of conformance to quality standards of education (Amir et al., 2020). Of total 5,130 higher secondary institutions in Pakistan, 61\% $(3,133)$ are private institutions. Overall, $51 \%$ of staff work in private educational institutions, while $49 \%$ of staff work in the private sector (Pakistan Education Statistics, 2018). Moreover, an increased enrollment trend has been observed in private institutions at the higher secondary level. Furthermore, private institutions are in the constant competition thus need to improve their performance for survival and growth. Private institutions are more accountable for performance than public institutions to secure the desired market share as the admissions for the next session largely depend on the previous year's performance. Private institutions are in a position to embrace service innovation because of less structural complexities. Thus, conferring to the objectives of this study, collecting data from the staff of private higher secondary educational institutions would be a more suitable approach. 


\section{Sampling Technique and Survey Procedure}

The multistage sampling technique was used to collect data from employees. The multistage sampling technique is appropriate when the target population is too vast or spread over a wide geographic area (Etikan \& Bala, 2017). Punjab province has been selected in this study to collect data from respondents because it is the largest province with a 52.95\% population. Moreover, the Punjab province has more educational institutions than other provinces (BISE, 2018; PHEC, 2019). First, three clusters (Zones) were developed based on geographical regions. Each zone contained three divisions, a total of nine divisions (sub-clusters). Those nine divisions were segregated into 36 districts (Pakistan Bureau of Statistics, 2017). At the next stage, from each division, one district was randomly selected as the final clusters. Finally, three private higher secondary educational institutions were randomly selected from each district, 27 institutions were randomly selected from nine districts.

A total of 372 questionnaires were distributed, and 340 were returned with a $91.58 \%$ response rate. In educational research, up to $80 \%$ response rate is appropriate (Fincham, 2008). Before the actual survey, a pre-test was conducted by three expert academicians to ensure the appropriateness of measuring instruments by assessing face validity, content validity, wording, formate, and other related aspects (Howard, 2018). Moreover, a declared participant pre-test was conducted with 30 respondents to ensure that the survey instrument has been interpreted similarly by the researcher and participants (Perneger et al., 2015). Finally, a pilot test was performed with 120 respondents to validate the instrument and ensure internal consistency. On pilot test data, exploratory factor analysis was conducted, and principal component analysis (PCA) with Varimax rotation technique was performed for all the dimensions of respective instrument. PCA with varimax rotation was performed for 14 items of organizational performance, and three factors were extracted with eigenvalue more than 1, explaining $69.410 \%$ of the total variance. In the HRM practices instrument, PCA with varimax rotation was performed for recruitment and selection dimension, two factors explain $71.285 \%$ of the total variance. Total variance explained for training and development, performance appraisal managemen, carrer planning, employee involvelement, employment security, and compensation and rewards were 75.794\%, 75.103\%, 70.866\%, 64.631\%, 71.801\% and $67.204 \%$, respectively. PCA with varimax rotation was performed for two dimensions of service innovationb namely incremental and radical innovation, total variance explained $78.116 \%$ and $84.838 \%$, respectively. Total variance explained for organizational commitment dimensions; affective, continuance and normative commitment was explained $62.078 \%$, $63.841 \%$ and $78.841 \%$, respectively. Initially, 14 items were taken for organizational performace, 6 items were dropped during EFA process. From 40 initially taken items of HRM practoiices, 31 items were retained while 9 items were eliminated in EFA. For organizational commitment from 18 initially taken items, one item was dropped during EFA process.

\section{Instruments}

The multi-item measuring scale for the constructs was adapted from the literature.The constructs were measured on a 10-point interval rating scale ranging from 1 (strongly disagree) to 10 (strongly agree). The organizational performance instrument was adapted from the work of Quansah (2013). Initially, 14 items were employed whereas, six items were deleted during exploratory factor analysis. The remaining eight items were used in the final survey. The 
organizational commitment questionnaire developed by Allen and Meyer (1990) was employed to measure the commitment construct. Initially, the scale comprised 18 items; one item was eliminated during exploratory factor analysis, and the remaining seventeen items were used for the final survey. HRM practices instrument was adapted from the work of Quansah (2013). Initially, the instrument comprised 40 items. After the pilot test and exploratory factor analysis, nine items were eliminated due to low factor loading, and 31 items were retained to conduct the final study. The service innovation scale was adapted from Cheng and Krumwiede (2012), consisting of two dimensions: radical and incremental innovation, entailing three items each. For the internal consistency of the instrument, Cronbach's alpha was computed. Results of the KMO and Bartlett test of Suphericity and Cronbach alpha values are presented in Table 1.

Table 1

Results of KMO, Bartlett's Test and Cronbach Alpha

\begin{tabular}{|c|c|c|c|c|c|}
\hline No & Construct & Dimensions & $\mathrm{KMO}$ & Bartlett's P-value & Cronbach Alpha \\
\hline \multirow[t]{7}{*}{1} & \multirow[t]{7}{*}{ HRM Practices } & Recruitment \& Selection & .79 & .00 & .80 \\
\hline & & Training \& Development & .75 & .00 & .72 \\
\hline & & Performance Appraisal & .77 & .00 & .82 \\
\hline & & Career Planning & .83 & .00 & .76 \\
\hline & & Employee Involvement & .74 & .00 & .72 \\
\hline & & Employment Security & .83 & .00 & .80 \\
\hline & & Compensation \& Rewards & .83 & .00 & .87 \\
\hline 2 & Organizational Performance & & .85 & .00 & .85 \\
\hline \multirow[t]{2}{*}{3} & \multirow[t]{2}{*}{ Service Innovation } & Radical Innovation & .73 & .00 & .89 \\
\hline & & Incremental Innovation & .71 & .00 & .82 \\
\hline \multirow[t]{3}{*}{4} & \multirow[t]{3}{*}{ Organizational Commitment } & Affective Commitment & .81 & .00 & .79 \\
\hline & & Continuance Commitment & .77 & .00 & .84 \\
\hline & & Normative Commitment & .91 & .00 & .86 \\
\hline
\end{tabular}

\section{Respondents' demographic}

Respondents' demographic details are presented in Table 2. Of total 340 respondents, $56.2 \%$ (191) were male, and $43.8 \%$ (149) were female participants. In age consideration, most respondents $(\mathrm{N}=100,29.4 \%)$ resided in the age group of $46-55$ years. The maximum number of respondents $(\mathrm{N}=227,66.8 \%)$ were M.Phil qualified, while $101(29.7 \%)$ respondents had a Master's degree. Furthermore, 77 respondents had 3 to 10 years of experience. Majority of respondents $(\mathrm{N}=113,33.2 \%)$ earned between PKR 41,000 to 55,000. Permanent staff members comprised $85 \%$, while maximum respondents $(89.7 \%)$ belonged to an academic department. 
Table 2

Respondents' Demographic Profile

\begin{tabular}{|c|c|c|c|}
\hline No & Respondents Profile $(\mathrm{N}=340)$ & $f$ & $\%$ \\
\hline \multirow[t]{4}{*}{1} & Gender & & \\
\hline & Male & 191 & 56.2 \\
\hline & Female & 149 & 43.8 \\
\hline & Total & 340 & 100 \\
\hline \multirow[t]{7}{*}{2} & Age in years & & \\
\hline & Below 25 & 36 & 10.6 \\
\hline & $26-35$ & 61 & 17.9 \\
\hline & $36-45$ & 93 & 27.4 \\
\hline & $46-55$ & 100 & 29.4 \\
\hline & Above 55 & 50 & 14.7 \\
\hline & Total & 340 & 100 \\
\hline \multirow[t]{6}{*}{3} & Qualification & & \\
\hline & Graduation & 4 & 1.2 \\
\hline & Masters & 101 & 29.7 \\
\hline & M.Phil. & 227 & 66.8 \\
\hline & $\mathrm{PhD}$ & 8 & 2.4 \\
\hline & Total & 340 & 100 \\
\hline \multirow[t]{7}{*}{4} & Experience & & \\
\hline & Less than 2 years & 57 & 16.8 \\
\hline & $3-10$ years & 77 & 22.6 \\
\hline & $11-20$ years & 121 & 35.6 \\
\hline & 21-30 years & 72 & 21.2 \\
\hline & Above 30 years & 13 & 3.8 \\
\hline & Total & 340 & 100 \\
\hline \multirow[t]{7}{*}{5} & Income in rupees & & \\
\hline & Below 25,000 & 15 & 4.4 \\
\hline & 26,000 to 40,000 & 67 & 19.7 \\
\hline & 41,000 to 55,000 & 113 & 33.2 \\
\hline & 56,000 to 70,000 & 98 & 28.8 \\
\hline & Above 70,000 & 47 & 13.8 \\
\hline & Total & 340 & 100 \\
\hline \multirow[t]{4}{*}{6} & Job & & \\
\hline & Permanent & 289 & .85 \\
\hline & On contract base & 51 & .15 \\
\hline & Total & 340 & 100 \\
\hline \multirow[t]{4}{*}{7} & Department & & \\
\hline & Administrative staff & 35 & 10.3 \\
\hline & Academic staff & 305 & 89.7 \\
\hline & Total & 340 & 100 \\
\hline \multirow[t]{4}{*}{8} & Training & & \\
\hline & Yes & 316 & 92.9 \\
\hline & No & 24 & 7.1 \\
\hline & Total & 340 & 100 \\
\hline
\end{tabular}

\section{Common Method Variance}

Common Method Variance (CMV) bias may arise due to utilizing self-reported data collection measures from the same respondent group (Podsakoff et al., 2012). In this study, the potential existence of CMV was examined with Harman's single-factor method to investigate whether a single factor was accountable for variance in the data. Overall, CMV analysis indicated that the 11 distinct factors accounted for $79.407 \%$ of the total variance. However, the first unrotated factor detained only $46.029 \%$ variance in the data. Hence, results indicated that common method variance did not influence the results of the analysis. 


\section{Analysis and Results}

\section{Measurement Model}

SEM is used for data analysis. First, the latent constructs were validated through CFA and then executed path analysis in the structural model. The unidimensionality, validity, and reliability of measurement models in CFA were confirmed (Asnawi et al., 2019). Construct validity was assessed through model fitness indices. A good model fit required RMSEA < .08, TLI, NFI, CFI, GFI $>.90$ with p-value $<.005$. Measurement model ensured model fitness by obtaining good fitness scores of $\chi^{2}(188 / 202.848), \chi^{2} / \mathrm{df}=1.07$, $\mathrm{p}$-value $<.005, \mathrm{RMSEA}=.061, \mathrm{CFI}=$ $.93, \mathrm{TLI}=.98, \mathrm{NFI}=.91$ and $\mathrm{GFI}=.98$. All the obtained values were acceptable and met the threshold (Hair et al., 2014). Convergent validity was assessed through AVE, and reliability was confirmed by calculating CR. To ensure unidimensionality, all the factor loadings should be greater than .60, while AVE > .50 and CR > .60 indicate statistical significance (Hair et al., 2014). Factor loadings, CR, and AVE values are presented in Table 3.

Table 3

Factor loadings, AVE and CR values

\begin{tabular}{|c|c|c|c|c|c|c|}
\hline Construct & Dimensions & Sub-dimensions & Items & Factor Loading & CR (> .60) & $\operatorname{AVE}(>.50)$ \\
\hline \multirow[t]{31}{*}{ HRM Practices } & \multirow{6}{*}{$\begin{array}{l}\text { Recruitment \& } \\
\text { Selection }\end{array}$} & \multirow[t]{2}{*}{ Eligibility } & EL1 & .72 & \multirow[t]{6}{*}{.88} & \multirow[t]{6}{*}{.55} \\
\hline & & & EL2 & .76 & & \\
\hline & & \multirow[t]{4}{*}{ Procedure } & PR1 & .70 & & \\
\hline & & & PR2 & .80 & & \\
\hline & & & PR3 & .74 & & \\
\hline & & & PR4 & .73 & & \\
\hline & \multirow{6}{*}{$\begin{array}{l}\text { Training \& } \\
\text { Development }\end{array}$} & \multirow[t]{2}{*}{ Initiation } & INI1 & .71 & \multirow[t]{6}{*}{.86} & \multirow[t]{6}{*}{.52} \\
\hline & & & INI2 & .74 & & \\
\hline & & \multirow[t]{4}{*}{ Practical } & PT1 & .70 & & \\
\hline & & & PT2 & .66 & & \\
\hline & & & РT3 & .76 & & \\
\hline & & & PT4 & .76 & & \\
\hline & \multirow{5}{*}{$\begin{array}{l}\text { Performance } \\
\text { Appraisal } \\
\text { Management }\end{array}$} & \multirow[t]{3}{*}{ Input } & IP1 & .80 & \multirow[t]{5}{*}{.89} & \multirow[t]{5}{*}{.64} \\
\hline & & & IP2 & .83 & & \\
\hline & & & IP3 & .82 & & \\
\hline & & \multirow[t]{2}{*}{ Retention Strategy } & RS1 & .79 & & \\
\hline & & & RS2 & .76 & & \\
\hline & \multirow[t]{5}{*}{ Career Planning } & \multirow[t]{3}{*}{ Responsible } & RE1 & .82 & \multirow[t]{5}{*}{.87} & \multirow[t]{5}{*}{.59} \\
\hline & & & RE2 & .79 & & \\
\hline & & & RE3 & .76 & & \\
\hline & & \multirow[t]{2}{*}{ Growth } & GR1 & .79 & & \\
\hline & & & GR2 & .72 & & \\
\hline & \multirow{3}{*}{$\begin{array}{l}\text { Employee } \\
\text { Involvement }\end{array}$} & & EI1 & .84 & \multirow[t]{3}{*}{.89} & \multirow[t]{3}{*}{.73} \\
\hline & & & EI2 & .87 & & \\
\hline & & & $\mathrm{EI} 3$ & .86 & & \\
\hline & \multirow{2}{*}{\multicolumn{2}{|c|}{$\begin{array}{l}\text { Employment } \\
\text { Security }\end{array}$}} & ES1 & .80 & \multirow[t]{2}{*}{.86} & \multirow[t]{2}{*}{.76} \\
\hline & & & ES2 & .94 & & \\
\hline & Compensation \& & & CR1 & .69 & .80 & .52 \\
\hline & Rewards & & $\mathrm{CR} 2$ & .71 & & \\
\hline & & & CR3 & .71 & & \\
\hline & & & CR4 & .74 & & \\
\hline Service Innovation & Radical innovation & & RAD1 & .80 & .85 & .66 \\
\hline & & & RAD2 & .83 & & \\
\hline & & & RAD3 & .82 & & \\
\hline & Incremental innovation & & INC1 & .75 & .80 & .58 \\
\hline & & & INC2 & .79 & & \\
\hline
\end{tabular}




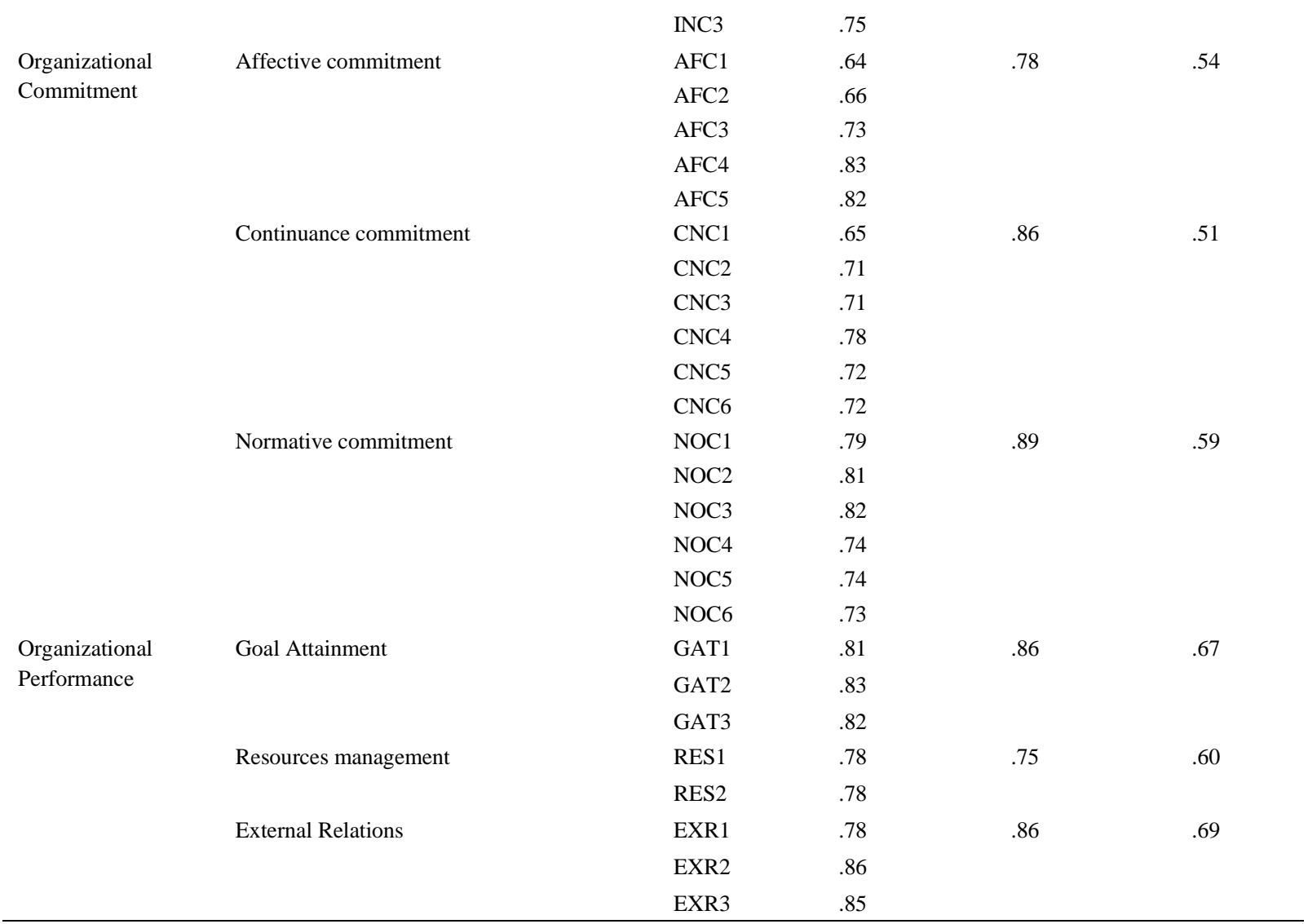

The measurement model of this study is complicated, constructs are higher-order with a certain number of dimensions, sub-dimensions, and measuring items. According to the recommendation of Awang (2015), individual CFA was executed for HRM practices, service innovation, organizational commitment, and organizational performance, and higher-order constructs were simplified through the item parceling process. Sixty-two items of four constructs were parcelled into fifteen representative components (Matsunaga, 2008). Those parcelled items were combined to performed pooled-CFA. Fator loading, AVE, and CR values of pooled measurement model are presented in Table 4.

Table 4

AVE and CR of Parceled Constructs in Pooled Measurement Model

\begin{tabular}{|c|c|c|c|c|c|}
\hline No & Construct & Item & Factor Loading & CR (above 0.6) & AVE (above 0.5) \\
\hline 1 & HRM Practices & $\begin{array}{l}\text { Recruitment and Selection } \\
\text { Training and development } \\
\text { Performance appraisal management } \\
\text { Career planning } \\
\text { Employment Security } \\
\text { Compensation and rewards } \\
\text { Employee Involvement }\end{array}$ & $\begin{array}{l}.83 \\
.62 \\
.69 \\
.83 \\
.78 \\
.84 \\
.86\end{array}$ & .91 & .59 \\
\hline 2 & Service Innovation & $\begin{array}{l}\text { Radical } \\
\text { Incremental }\end{array}$ & $\begin{array}{l}.81 \\
.81\end{array}$ & .79 & .65 \\
\hline 3 & $\begin{array}{l}\text { Organizational } \\
\text { Commitment }\end{array}$ & $\begin{array}{l}\text { Affective } \\
\text { Continuance } \\
\text { Normative }\end{array}$ & $\begin{array}{l}.81 \\
.81 \\
.65\end{array}$ & .77 & .53 \\
\hline 4 & $\begin{array}{l}\text { Organizational } \\
\text { performance }\end{array}$ & $\begin{array}{l}\text { Goal attainment } \\
\text { Resources } \\
\text { External relationship }\end{array}$ & $\begin{array}{l}.66 \\
.77 \\
.85\end{array}$ & .80 & .58 \\
\hline
\end{tabular}


Discriminant validity was calculated by taking the square root of AVE. The level of correlation among constructs of the measurement model less than .85 ensured the problem of multicollinearity and redundant items do not exist (Hair et al., 2014). Table 5 presents the discriminant validity of the model.

Table 5

Summary of Discriminant Validity Index

\begin{tabular}{lcccc}
\hline Construct & HRM Practices & Service Innovation & Organizational Commitment & Organizational Performance \\
\hline HRM Practices & $\mathbf{. 7 7}$ & & & \\
Service Innovation & .43 & $\mathbf{. 1}$ & & \\
Organizational Commitment & .48 & .53 & $\mathbf{. 3}$ & $\mathbf{. 7 6}$ \\
Organizational Performance & .55 & .67 & .72 & \\
\hline
\end{tabular}

\section{Structural Model}

Structural model analysis was performed to compute regressions paths and standardized regression weights. The value of $\mathrm{R}^{2}$ is .78 , which indicates that $78 \%$ of organizational performance could be attained by HRM practices, service innovation, and organizational commitment. Fitness index of structural model are also acceptable $(\chi 2 / \mathrm{df}=2.0, p<.005$, RMSEA $=.78, \mathrm{CFI}=.94, \mathrm{TLI}=.92, \mathrm{NFI}=.98, \mathrm{GFI}=.96$ ). Results of the structural model indicated that the structure of the proposed model adequately describes relationships among constructs (Hair et al., 2014).

\section{Hypothesis Testing}

SEM technique was used to test the hypotheses. Hypotheses $\mathrm{H}_{1}-\mathrm{H}_{5}$ examine the direct causal relationship, while $\mathrm{H}_{6}$ and $\mathrm{H}_{7}$ examine the mediational influence. HRM practices had positive effects on service innovation $\left(\mathrm{H}_{1}\right)(\beta=.59, p=.001)$. HRM practices had a positive effect on organizational commitment $\left(\mathrm{H}_{2}\right)(\beta=.59, p=.001)$. HRM practices did not have a positive influence on organizational performance $(\beta=.12, p=.07)$. Effect of service innovation $(\beta=$ $.33, p=.001)$ and organizational commitment $(\beta=.64, p=.001)$ on organizational performance is statistically positive. $\mathrm{H}_{1}, \mathrm{H}_{2}, \mathrm{H}_{4}$, and $\mathrm{H}_{5}$ are supported while $\mathrm{H}_{3}$ is not supported as presented in Table 5.

\section{Mediation Effect}

Bootstrapping Maximum Likelihood Estimation (MLE) method with 1000 bootstrap samples and $95 \%$ confidence interval was used to examine the mediational effect of service innovation and organizational commitment. As presented in Table 6, the indirect effect of (HRM practices $\rightarrow$ service innovation $\rightarrow$ organizational performance) revealed was positively significant $(.59 * .33 ; \beta=.20, p<.001)$. Whereas the direct effects of (HRM practices $\rightarrow$ organizational performance) were not significant $(\beta=.12, p=.07)$. Thus, $\mathrm{H}_{6}$ is supported, and service innovation fully mediates the effect of HRM practices on organizational performance. The indirect effect of HRM practices, organizational commitment, and organizational performance was positively significant $\left(.59^{*} .64, \beta=.38, p<.001\right)$, while beta value of direct effect was not positively significant $(\beta=.12, p=.07) . \mathrm{H}_{7}$ is supported, and organizational commitment act as a full mediator. 
Table 6

Results of Hypotheses Test

\begin{tabular}{lccccccl}
\hline Construct & Path & \multicolumn{1}{c}{ Construct } & B & SE & Critical Region & $p$ & Decision \\
\hline Service Innovation & $\leftarrow$ & HRM Practices & .59 & .07 & 7.62 & .000 & Supported \\
Organizational commitment & $\leftarrow$ & HRM Practices & .59 & .07 & 7.83 & .000 & Supported \\
Organizational Performance & $\leftarrow$ & HRM Practices & .12 & .06 & 1.79 & .07 & Not Supported \\
Organizational Performance & $\leftarrow$ & Service Innovation & .33 & .05 & 6.22 & .000 & Supported \\
Organizational Performance & $\leftarrow$ & Organizational Commitment & .64 & .07 & 8.37 & .000 & Supported \\
\hline
\end{tabular}

\section{Discussions}

Results indicated that seven considered HRM practices (recruitment and selection, training and development, performance appraisal management, compensation and rewards, career planning, employee involvement, and employment security) predictor of service innovation. Execution of HRM practices facilitates the educational institutions to introduce and implement radical as well as incremental innovation. The fundamental assumption in the relationship of HRM and service innovation is that innovation is the first and foremost a human phenomenon (Kianto, Sáenz, \& Aramburu, 2017). In service organizations, the human resource and service provision process are inseparable. Implementation of HRM practices enhances employees' existing knowledge, capabilities, skills and encourages their participation with unique ideas essential to bring radical and incremental innovation in the services organizations (Mazzei, Flynn, \& Haynie, 2016). Second, findings indicated that HRM practices statistically influence the organizational commitment of higher secondary educational institutions. This result is consistent with Metwally's (2016) findings, which concluded that HRM practices are positively linked with affective, normative, and continuance organizational commitment. Third, organizational commitment and service innovation positively influence the organizational performance of educational institutions. These findings are similar to the results of Kassaw and Golga (2019). Fourth, the unique outcome of the present study is that HRM practices do not significantly influence organizational performance. In higher educational institutions, recruitment and selection practices are mostly inadequate to contribute to higher performance. Reward systems and performance appraisal management and did not assure higher motivation to perform better. HRM practices influence organizational performance through the mediational role of service innovation and organizational commitment.

\section{Theoretical Contributions}

The primary contribution of this study is the development of an integrated model that links HRM practices, service innovation, organizational commitment, and performance in private higher secondary educational institutions of Punjab, Pakistan. Organizational performance was measured with the dimensions of goal accomplishment, resource management, and external relationships. These dimensions have not been previously considered to evaluate the performance of educational institutions, specifically in the context of private higher secondary educational institutions of Punjab, Pakistan. This study contributed to the body of knowledge by providing insights about the mediational role of service innovation and organizational commitment that has not been examined before in the context of higher secondary educational institutions. Lastly, the notable contribution of this study is to examine the role of service innovation in the educational context. Consideration of service innovation in the education sector warrant better solutions to performance issues and offer valued theoretical and 
methodological insights to the innovation and organizational literature (Carvalho \& Goodyear, 2018).

\section{Practical Contributions}

The findings of this study lend valuable insights to the education sector in general and the higher secondary educational institutions in particular. Institutions should work on the quality of their academic staff by executing appropriate HRM practices to enhance performance. Moreover, findings asserted that upgrading service offerings and delivery processes through the embracement of service innovation could improve the performance of educational institutions. With the advent of globalization, the world is rapidly changing, so are technological trends. Correspondingly, service innovation has become imperative and challenging for educational institutions. This disruptive approach demands continuous incremental and radical changes to improve service quality, ensure excellence, target new customer groups and satisfy the stakeholders.

\section{Limitations and Recommendations}

This study has some limitations. Firstly, the scope of this study is limited as it considered the influence of HRM practices, service innovation, and organizational commitment on the performance of private higher secondary educational institutions of Pakistan. Secondly, data was collected from private institutions located in nine districts of Punjab province. Therefore, the generalizability of this study in a methodological context might be limited. Thirdly, due to time and budgetary constraints, this study is cross-sectional. Although the findings of this study disclose an insignificant direct effect of HRM practices on organizational performance, a longitudinal study can be conducted to gain better insights into the impact of HRM practices on organizational performance over a longer period. Conferring to service innovation with incremental and radical aspects, the concept of market innovation and organizational innovation could also be considered, and their effect on organizational performance should be examined. Particularly the impact of marketing innovation on performance needs to be assessed in services and non-profit organizations.

\section{References}

Abebe, T., \& Markos, B. (2016). The relationship between job satisfaction and organizational commitment in public higher education institution: The case of Arba-Minch University, Ethiopia. International Journal of Research in Business Management, 4(8), 2347-4572.

Al-kalouti, K. V., Kumar, N., Garza-Reyes, Upadhyay, \& Zwiegelaar, (2020). Investigating innovation capability and organizational performance in service firms. Strategic Change, 29(1), 103-113.

Allen, N., \& Meyer, J. (1990). The measureent and anyeecedents of affective, normative and continuance commitment to the organization. Journal of Occupational Psychology, 63, 1-18.

Allui, A., \& Sahni, J. (2016). Strategic human resource management in higher education institutions: Empirical evidence from Saudi. Procedia - Social and Behavioral Sciences, 235, 361-371.

AL-TAL, Jaber Yousef M. \& Lawrence, O. E. (2019). Knowledge-based HR Practices and Innovation in SMEs. Organizacija, Sciendo, 52(1), 6-21.

Aman, Q., Noreen, T., Khan, I., Ali, R., \& Yasin, A. (2018). The impact of human resource management practices on innovative ability of employees moderated by organizational culture. International Journal of Organizational Leadership, $7(4), 426-439$. 
Amir, S., Sharf, N., \& Khan, R. A. (2020). Pakistan's education system: An analysis of education policies and drawbacks. Electronic Research Journal of Social Sciences and Humanities, 2(1), 2-11.

Asnawi, A., Awang, Z., Afthanorhan, A., Mohamad, M., \& Karim, F. (2019). The influence of hospital image and service quality on patients' satisfaction and loyalty. Management Science Letters, 9(6), 911-920.

Awan, M. T. (2019). Higher education institutions and the performance management. Library Philosophy and Practice (eJournal).

Awang, Z. Bin. (2015). SEM made simple. The gentle approach in learning structural equation modeling. Malaysian Postgraduate Workshop SERIES (MPWS) Publisher. Bangi. Selangor Malaysia.

Bahjat Abdallah, A., Yousef Obeidat, B., Osama Aqqad, N., Khalil Al Janini, M. N., \& Dahiyat, S. E. (2017). An integrated model of job involvement, job satisfaction and organizational commitment: A structural analysis in Jordan's banking sector. Communications and Network, 09(01), 28-53.

Barney, J. B. (1991). Firm resources and sustained competitive Advantage. Journal of Management, 17(1), 1-22.

Barney, J. B., Ketchen Jr, D. J., \& Wright, M. (2011). The future of resource-based theory: Revitalization or decline? Journal of Management, 37(5), 1299-1315.

BISE, (2018). Summative Evaluation of GPE's Country-level Support to Education. Batch 2.

Brito, R. P. de, \& Oliveira, L. B. de. (2016). The relationship between human resource management and organizational performance. Brazilian Business Review, 13(3), 90-110. https://doi.org/10.15728/bbr.2016.13.3.5

Bryson, A., Stokes, L., \& Wilkinson, D. (2018). Can HRM improve schools' performance? Labour: Review of Labour Economics and Industrial Relations, 11348.

Cameron, V., \& Grootenboer, P. (2020). Human resource management in education: recruitment and selection of teachers. International Journal of Management and Applied Science, 4(2), 89-94.

Carvalho, L., \& Goodyear, P. (2018). Design learning networks and service innovation. Design Studies, 55, $27-53$.

Cheng, C.C., \& Krumwiede, D. (2012). The role of service innovation in the market orientation - New service performance linkage. Technovation 32(s 7-8):487-497.

Dastmalchian, A., Bacon, N., McNeil, N., Steinke, C., Blyton, P., Satish Kumar, M., Bayraktar, S., Auer-Rizzi, W., Bodla, A. A., Cotton, R., Craig, T., Ertenu, B., Habibi, M., Huang, H. J., İmer, H. P., Isa, C. R., Ismail, A., Jiang, Y., Kabasakal, H., ... Varnali, R. (2020). High-performance work systems and organizational performance across societal cultures. Journal of International Business Studies, 51(3), 353-388.

Dede, N. P. (2019). Enhancing employee innovative work behavior through human resource management practices. In Handbook of Research on Managerial Thinking in Global Business Economics (pp. 1-21). IGI Global.

Diaz-Fernandez, M., Bornay-Barrachina, M., \& Lopez-Cabrales, A. (2017). HRM practices and innovation performance: a panel-data approach. International Journal of Manpower, 38(3), 354-372.

Do, H., Budhwar, P. S., \& Patel, C. (2018). Relationship between innovation-led HR policy, strategy, and firm performance: A serial mediation investigation. Human Resource Management, 57(5), 1271-1284.

Ebraze, A., Rabbanikhah, F., Manafi, F., \& Moradi, R. (2019). Prediction of Organizational Commitment Based on Job Satisfaction Dimensions among Employees of the Ministry of Health and Medical Education. Caspian Journal of Health Research, 4(2), 49-53.

Economic Survey of Pakistan. (2018). Education. 157.

Ehijiele, E. (2018). The Influence of Employees Commitment on Organizational Performance in Nigeria. International Journal of Research Publication, 8(1), 1-12.

Ehrami, M. (2017). The effectiveness of organizational learning and innovation on financial performance of service-based organizations (Dey Bank and Insurance). The Turkish Online Journal of Design Art and COmmunication TOJDAC, April(April), 1227-1235.

El-Hilali, N., Al-Jaber, S., \& Hussein, L. (2015). Students' satisfaction, achievement and absorption capacity in higher education. Procedia - Social and Behavioral Sciences, 177, 420-427.

Etikan, I., \& Bala, K. (2017). Sampling and sampling methods. Biometrics and Biostatistics International Journal, 5(6), 215217.

Engin Aydoğan and Özcan Arslan, (2020). HRM practices and organizational commitment link: maritime scope. International Journal of Organizational Analysis. 29(1), 260-276. https://doi.org/10.1108/IJOA-02-2020-2038

Ferreira, J., Cardim, S., \& Coelho, A. (2021). Dynamic capabilities and mediating effects of innovation on the competitive advantage and firm's performance: the moderating role of organizational learning capability. Journal of the Knowledge Economy, 12(2), 620-644. 
Fincham, J. E. (2008). Response rates and responsiveness for surveys, standards, and the Journal. American Journal of Pharmaceutical Education, 72(2), 43.

Gyurák Babel’ová, Z., Stareček, A., Koltnerová, K., \& Cagáňová, D. (2020). Perceived organizational performance in recruiting and retaining employees with respect to different generational groups of employees and sustainable human resource management. Sustainability (Switzerland), 12(2).

Hair Jr, J. F., Gabriel, M. L., \& Patel, V. K. (2014). Modeling Covariance Based Structural Equations (CB-SEM) with AMOS: Guidance on its application as a Marketing Research Tool. Revista Brasileira de Marketing, 13(2), 44-55.

Howard, M. C. (2018). Scale pretesting. Practical Assessment, Research and Evaluation, 23(5), 1-14.

Hunter, R. (2020). WENR; World Education News And Reviews. Retrieved From Education System Profiles; Education In Pakistan: Https://Wenr.Wes.Org/2020/02/Education-In-Pakistan.

Idrus, N. A., Othman, A., \& Faizuddin, A. (2018). The practices of human resource management among headmasters in primary schools: A case study of selected national and private schools in Malaysia. IIUM Journal of Educational Studies, $5(1), 26-48$.

Jashari, A., \& Kutllovci, E. (2020). The impact of human resource management practices on organizational performance case study: Manufacturing enterprises in Kosovo. Business: Theory and Practice, 21(1), 222-229.

Jawaad, M., Amir, A., Bashir, A., \& Hasan, T. (2019). Human resource practices and organizational commitment: The mediating role of job satisfaction in emerging economy. Cogent Business and Management, 6(1).

Kaliappen, N., \& Hilman, H. (2014). Does service innovation act as a mediator in differentiation strategy and organizational performance nexus? An empirical study. Asian Social Science, 10(11), 123-131.

Karakaş, A., Yasar, O., \& Yıldız, R. (2017). The effect of innovation activities on organizational performance: A research on hotel businesses. Journal of Recreation and Tourism Research, 4(1), 49-59.

Kassaw, E. S., \& Golga, D. N. (2019). Academic staffs' level of organizational commitment in higher educational setting: The case of Haramaya university. International Journal of Higher Education, 8(2), 87-100.

Khandakar, M.S.A. and Pangil, F. (2021), "The role of affective commitment on the relationship between human resource management practices and informal workplace learning", Higher Education, Skills and Work-Based Learning Vol. 11 No. 2, pp. 487-507.

Kianto, A., Sáenz, J., \& Aramburu, N. (2017). Knowledge-based human resource management practices, intellectual capital and innovation. Journal of Business Research, 81(September 2019), 11-20.

Kumari, M. P. V., \& Dubey, P. (2018). Employee performance and their organizational commitment in relation to HRM practices: A literature review. Journal of Business and Management, 20(4), 58-63.

Luna-Arocas, R., \& Lara, F. J. (2020). Talent management, affective organizational commitment and service performance in local government. International Journal of Environmental Research and Public Health, 17(13), 1-15.

Manthi, K., Kilika, \& Kimencu, L. (2018). How do human resource management practices predict employee turnover intentions: An empirical survey of teacher training colleges in Kenya. International Journal of Business Administration, 9(4), 201.

Matsunaga, M. (2008). Item parceling in structural equation modeling: A primer. Communication Methods and Measures, 2(4), 260-293.

Mazzei, M., Flynn, C., \& Haynie, J. (2016). Moving beyond initial success: Promoting innovation in small businesses through high-performance work practices. Business Horizons, 59, 51-60.

Metwally, D. (2016). Exploring the relationship between HR practices and organizational commitment in Egyptian organizations: The mediating effect of job satisfaction. International Journal of Business and Management Review, 4(1), $76-111$.

Mohamud, S. A., Hussein, J. M., \& Mohamud, S. A. (2018). the effect of employee commitment on organizational effectiveness: Case study of Waaya Arag and Beder Electronic Companies in Mogadishu- Somalia. Internnational Journal of Current Research, 10(3), 67333-67338.

Nataya, A., \& Sutanto, J. E. (2018). The effect of product innovation and service innovation towards marketing performance (Case Study on Plastic Producer in Surabaya). International Journal of Business and Management Invention (IJBMI), 7(8), 61-66. Retrieved from http://dspace.uc.ac.id/handle/123456789/2472

Naviwala, N. (2016). Pakistan's education crisis: The real story. Wilson Center Asia Pogram, 18(6), 466-468.

Omar, R., Ali, , \& Masrom, M. (2020). The relationship between Human Resource Management and organisational performance in construction: Synthesis of HRM models. Journal of Critical Reviews, 7(7), 1151-1158.

Pakistan Bureau of Statistics (2017). Pakistan statistical year book, 2017, Government of Pakistan statistics division.

Pakistan Education Satistics, (2018). Pakistan Education System. Pakistan Education Satistics Unicef, 25, 208. 
Peachey, J. W., Burton, L. J., \& Wells, J. E. (2014). Examining the influence of transformational leadership, organizational commitment, job embeddedness, and job search behaviors on turnover intentions in intercollegiate athletics. Leadership and Organization Development Journal, 35(8), 740-755.

Perneger, T. V., Courvoisier, H., \& Gayet-Ageron, A. (2015). Sample size for pre-tests of questionnaires. Quality of Life Research, 24(1), 147-151.

PHEC. (2019). Punjab Higher Education Commission Annual Report (2019).

Poazi, F., Tamunosiki-Amadi, J., \& M Fems. (2017). The resource-base view of organization and innovation: Recognition of significant relationship in an organization. World Academy of Science, Engineering and Technology, International Journal of Social, Behavioral, Educational, Economic, Business and Industrial Engineering, 11(3), 697-704.

Podsakoff, P. M., MacKenzie, S. B., \& Podsakoff, N. P. (2012). Sources of method bias in social science research and recommendations on how to control it. Annual Review of Psychology, 63(1), 539-569.

Princy, K., \& Rebeka, E. (2019). Employee commitment on organizational performance. International Journal of Recent Technology and Engineering, 8(3), 891-895.

Quansah, N. (2013). The impact of HRM practices on organisational performance: The case study of some selected rural banks. Kwame Nkrumah University of Science and Technology (KNUST).

Rajapathirana, R. P., \& Hui, Y. (2018). Relationship between innovation capability, innovation type, and firm performance. Journal of Innovation and Knowledge, 3(1), 44-55.

Rasool, S. F., Samma, M., Wang, M., Zhao, Y., \& Zhang, Y. (2019). How human resource management practices translate into sustainable organizational performance: The mediating role of product, process and knowledge innovation. Psychology Research and Behavior Management, 12, 1009-1025.

Santhanam, N., Kamalanabhan, T. J., Dyaram, L., \& Ziegler, H. (2017). Impact of human resource management practices on employee turnover intentions: Moderating role of psychological contract breach. Journal of Indian Business Research, 9(3), 212-228.

Seeck, H., \& Diehl, M. R. (2017). A literature review on HRM and innovation-taking stock and future directions. International Journal of Human Resource Management, 28(6), 913-944.

Sethibe, T., \& Steyn, R. (2016). Innovation and organisational performance: A critical review of the instruments used to measure organisational performance. The Southern African Journal of Entrepreneurship and Small Business Management, $8(1), 12$.

Sharma, V., \& Dada Bhat, R. (2020). Co-creation and service innovation as performance indicators in the hospitality industry. Journal of Tourism, Hospitality and Culinary Arts, 12(2), 76-95.

Sriviboon, C., \& Jermsittiparsert, K. (2019). Influence of human resource practices on Thai pharmaceutical firm performance with moderating role of job involvement. Systematic Reviews in Pharmacy, 10(2), 234-243.

Takeuchi, R., Lepak, D. P., Wang, H., \& Takeuchi, K. (2007). An empirical examination of the mechanisms mediating between high-performance work systems and the performance of Japanese organizations. Journal of Applied Psychology, 92(4), 1069-1083.

Teece, D. J. (2007). Explicating dynamic capabilities: The nature and micro-foundations of (sustainable) enterprise performance. Strategic Management Journal, 28, 1319-1350.

Teece, D. J., Pisano, G., \& Shuen, A. (1997). Dynamic capabilities and strategic management. Knowledge and Strategy, 18(March), 77-116.

Tsai, K. H., \& Yang, S. Y. (2013). Firm innovativeness and business performance: The joint moderating effects of market turbulence and competition. Industrial Marketing Management, 42(8), 1279-1294.

UNESCO, (2018). Education for sustainable development and the SDGs: Learning to act, learning to achieve. Policy brief. Advancing ESD Policy. Advancing ESD Policy, 6.

Wasti, S. A., Peterson, M. F., Breitsohl, H., Cohen, A., Jørgensen, F., de Aguiar Rodrigues, A. C., Weng, Q., \& Xu, X. (2016). Location, location, location: Contextualizing workplace commitment. Journal of Organizational Behavior, 37(4), 613-632.

Wolf, P. J., \& Lasserre-Cortez, S. (2018). Special education enrollment and classifcation in Louisiana charter schools and traditional schools (REL 2018-288). Washington, DC: U.S. Department of Education, Institute of Education Sciences, National Center for Education Evaluation and Regional Assistance, Regional Educational Laboratory Southwest. Retrieved from http://ies.ed.gov/ncee/edlabs.

Zawawi, N. F. M., Wahab, S. A., Al-Mamun, A., Yaacob, A. S., Kumar, N., \& Fazal, S. A. (2016). Defining the Concept of Innovation and Firm Innovativeness: A Critical Analysis from Resorce-Based View Perspective. International Journal of Business and Management, 11(6), 87-94.

Zou, S., \& Stan, S. (1998). The determinants of export performance: A review of the empirical literature between 1987 and 1997. International Marketing Review, 15(5), 333-356. 
World Education Services (2020). Education in Pakistan. Retrieved online 22/06/2020. https://wenr.wes.org./2020/02 education-in-Pakistan.

\section{Acknowledgements}

Not applicable.

\section{Disclosure Statement}

No potential conflict of interest was reported by the authors.

\section{Funding Acknowledgements}

This work is supported by Internal Grant Agency (IGA) of Tomas Bata University in Zlín, the Czech Republic, under project No. IGA/FAME/ 2021/009.

\section{Open Access}

The International Journal of Organizational Leadership publishes open access articles under the terms of the Creative Commons Attribution (CC BY) License, which permits use, distribution, and reproduction in any medium, provided the original work is properly cited. 